\title{
Biological Activities of Wild Asparagus (Asparagus acutifolius L.)
}

\section{Arzu Kaska (iD),1, Nahide Deniz ${ }^{2}$, Ramazan Mammadov ${ }^{2}$}

\author{
${ }^{1}$ Department of Science and Mathematics, Faculty of Education, Pamukkale University, Denizli, Turkey \\ ${ }^{2}$ Department of Biology, Faculty of Arts and Science, Pamukkale University, Denizli, Turkey
}

\begin{abstract}
Asparagus acutifolius L. (wild asparagus) is an edible plant species that is widely distributed throughout the Mediterranean. This study was designed to investigate the phenolic compounds, antioxidant, and cytotoxic activities of ethanol and water extracts of different parts (fruits and leaves) of A. acutifolius. The antioxidant activities of these extracts were analyzed using scavenging methods (DPPH and ABTS scavenging activity), the $\beta$-carotene/linoleic acid test system and the phosphomolybdenum method. Among the evaluations of the ethanol and water extracts of the different parts of A. acutifolius, the ethanol extract of the leaves was shown to have the highest amount of radical scavenging activities (DPPH, 0.383 $\mathrm{mg} / \mathrm{mL}$ and ABTS, $0.145 \mathrm{mg} / \mathrm{mL}$ ). Each extract of A. acutifolius exhibited strong antioxidant capacities with the $\beta$-carotene/Linoleic acid test system. For the phosphomolybdenum method, the antioxidant capacity of the extracts was in the range of 8.89-45.29 $\mu \mathrm{g} / \mathrm{mg}$ and each extract exhibited high cytotoxic activities. The results will provide additional information for future studies on the biological activities of $A$. acutifolius, while also helping us to understand the importance of this species.
\end{abstract}

\section{ARTICLE HISTORY}

Received: 17 May 2018

Revised: 29 August 2018

Accepted: 04 September 2018

\section{KEYWORDS}

Asparagus acutifolius, Antioxidant,

Cytotoxic, Wild Asparagus.

\section{INTRODUCTION}

Not only plants used as food but due to their medical benefits they can also be used for the treatment of various diseases. Evaluating significance of their potential can therefore help in further understanding the medicinal value of these plants [1]. For this reason, medicinal or edible plants have been intensively investigated in recent years in order to find compounds that have antioxidant capacities, capable of protecting against a number of diseases [2].

The Asparagus genus includes more than 250 species that are of interest particularly in terms of their nutritional and medicinal use [3]. The genus is a valuable source of significant compounds and essential nutrients, oligosaccharides [4], vitamins and minerals [5]. Moreover, these plants contain flavonoids (mainly rutin) and phenolic compounds, both of which have powerful antioxidant properties [6]. One of the species belonging to the Asparagus genus is Asparagus acutifolius L. (wild asparagus), which is a native plant species commonly found throughout the Mediterranean [7]. A. acutifolius is an herbaceous, perennial, evergreen 
dioecious species with a tetraploid set of chromosomes [8, 9]. A wild edible plant, it has long been harvested and used in a variety of traditional cuisines throughout the Mediterranean [10]. A. acutifolius is rich in flavonoids and vitamin $\mathrm{C}$, showing high antioxidant activity [11]. In western Anatolia, Turkey, the young shoots of this plant are consumed as vegetables and are added to dishes such as omelet and soups. Furthermore, A. acutifolius is considered to be a health-giving ingredient and is used in traditional medicinal treatments as a diuretic and antineuralgic [12-15].

Consequently, more research is required on the biological activities of this edible wild plant. We therefore consider that within the scope of this study A. acutifolius is a plant worthy of additional investigation. At the same time, while research exists on the antioxidant capacity and phenolic content of $A$. acutifolius spears [10,15-18], to the best of our knowledge there is virtually no information on the biological activities of $A$. acutifolius fruit and leaves. With these aspects in mind, the objectives of the present study are to evaluate the antioxidant capacities, the cytotoxic activity and the total phenolic, flavonoid and tannin contents of the ethanol and water extracts of various parts from A. acutifolius.

\section{MATERIAL AND METHODS}

\subsection{Plant Materials}

Asparagus acutifolius L were collected from Çamlık, Denizli, Turkey, in June 2017. The taxonomic identification of the plant material was confirmed by Dr. Mehmet Çiçek, a plant taxonomist from the Biology Department of Pamukkale University, Denizli, Turkey. A voucher specimen (Asparagus acutifolius L; Herbarium No: 2017-99-1) was deposited at the private herbarium of M. Çiçek (PAU) at Pamukkale University (Denizli, Turkey).

\subsection{Preparation of The Plant Extracts}

The aerial parts (fruit and leaves) of A. acutifolius were air-dried in the dark and powdered at our laboratory. Twenty grams of each sample were weighed into Erlenmeyer flasks and then $200 \mathrm{~mL}$ of ethanol $(96 \%)$ or water solvents were added to the samples. Extraction was carried out by shaking at $50{ }^{\circ} \mathrm{C}$ for $6 \mathrm{~h}$ in a temperature controlled shaker. The extract was then separated from the sample residue by filtration through Whatman No.1 filter paper, repeated twice and the solvent was evaporated at $40-50{ }^{\circ} \mathrm{C}$ using rotary evaporator (IKA RV10D, Staufen, Germany). All extracts were lyophilized (Labconco FreeZone, Kansas City, MO) and stored at $-20{ }^{\circ} \mathrm{C}$ until use. In the manuscript, we used three-letter acronyms, the first signifying the plant, the second the solvent used and the third the part of plant (AEF: Ethanol extract of fruits of A. acutifolius; AEL: Ethanol extract of leaves of A. acutifolius; AWF: Water extract of fruits of A. acutifolius AWL: Water extract of leaves of A. acutifolius.All the experiments were done in triplicates.

\subsection{Chemicals}

$\beta$-carotene, Linoleic acid, 2,2-Diphenyl-1-picrylhydrazyl radical (DPPH), 2,2'-azino-bis (3-ethylbenzothiazoline-6-sulfonic acid) (ABTS), Quercetin, Sodium phosphate, Gallic acid, methanol, chloroform and ethanol were purchased from Sigma-Aldrich. Butylated hydroxytoluene (BHT), Folin-Ciocalteu reagent and Tween 20 were purchased from Merck (Darmstadt, Germany). Other chemicals and solvents were of analytical grade.

\subsection{Determination of Total Antioxidant Activity}

\subsection{1. $\beta$-carotene/linoleic acid method}

The antioxidant activity of the plant extracts was determined according to the method of Amin and Tan [19]. One milliliter of $\beta$-carotene solution $(0.2 \mathrm{mg} / \mathrm{mL}$ chloroform $)$ was put into a round-bottom flask containing $0.02 \mathrm{~mL}$ of linoleic acid and $0.2 \mathrm{~mL}$ of $100 \%$ Tween 20 . The chloroform was evaporated using a rotary evaporator. Then, the mixture was diluted with 100 
$\mathrm{mL}$ of distilled water. The reaction mixture and one milliliter extracts $(1 \mathrm{mg} / \mathrm{mL})$ were placed in test tubes. The initial absorbances were immediately measured with a spectrophotometer at $470 \mathrm{~nm}$. The reaction mixture was incubated at $50{ }^{\circ} \mathrm{C}$ for 2 hours and the absorbance of this mixture was measured again. The same process was repeated with BHT as a positive control. The total antioxidant activity (AA) was calculated as follows:

$$
\mathrm{AA}=\left[1-\left(\mathrm{A}_{\mathrm{samp}}-\mathrm{A}_{\mathrm{co}}\right) /\left(\mathrm{A}_{\mathrm{samp}}^{\mathrm{o}}-\mathrm{A}_{\mathrm{co}}^{\mathrm{o}}\right)\right] \times 100
$$

( $\mathrm{A}_{\text {samp }}$ and $\mathrm{A}_{\mathrm{co}}$ absorbance at the initial time of the incubation of samples and control, respectively and $\mathrm{A}_{\text {samp }}^{\mathrm{o}}$ and $\mathrm{A}_{\text {co }}^{\mathrm{o}}$ : absorbance in the samples and control at $120 \mathrm{~min}$ ).

\subsubsection{Phosphomolybdenum method}

This was evaluated using the phosphomolybdenum method according to Prieto et al [20]. A reagent solution containing $0.6 \mathrm{M}$ sulfuric acid, $28 \mathrm{mM}$ sodium phosphate and $4 \mathrm{mM}$ ammonium molybdate was prepared and the reagent solution $(3 \mathrm{~mL})$ and $0.3 \mathrm{~mL}$ extract were mixed. The reaction mixture was incubated at $95^{\circ} \mathrm{C}$ for $90 \mathrm{~min}$. The absorbances of the mixtures were measured at $695 \mathrm{~nm}$ using a spectrophotometer. The antioxidant activity of the extracts was expressed as equivalence of ascorbic acid.

\subsection{Measurement of Radical Scavenging Activity}

\subsubsection{Free radical scavenging activity (DPPH)}

The DPPH free radical scavenging method is an antioxidant assay based on electron transfer. The DPPH method is a quick and simple way for calculating antioxidants by means of spectrophotometry. The scavenging activity of A. acutifolius extracts on DPPH radicals was measured according to the method of Meriga et al [21]. Different concentrations (0.2-1.0 $\mathrm{mg} / \mathrm{mL})$ of the extracts $(1 \mathrm{~mL})$ were mixed with $4 \mathrm{~mL}$ of DPPH radical methanolic solution. The reaction mixture was kept in a dark room for $30 \mathrm{~min}$. The absorbance measured at $517 \mathrm{~nm}$. BHT was used as a control. Results were expressed as $\mathrm{IC}_{50}$ values. The values of $\mathrm{IC}_{50}$ denote the concentration of the sample that is required to scavenge $50 \%$ of DPPH free radicals.

\subsubsection{ABTS radical cation scavenging activity}

The ABTS method was conducted according to the procedure of Shalaby and Shanab [22] with slight modifications. The ABTS cations were produced by reacting $7 \mathrm{mM}$ ABTS stock solution with $2.45 \mathrm{mM}$ potassium persulfate. The reaction mixture was kept in a dark room for $12-16 \mathrm{~h}$ before use. The absorbance $(0.700 \pm 0.05)$ of the diluted reacting mixture and ethanol (1:1) were measured at $734 \mathrm{~nm}$ for the study of the extracts. The ABTS solution was mixed with $0.1 \mathrm{~mL}$ of the extracts $(1 \mathrm{mg} / \mathrm{mL})$. The absorbance of the solutions were read at $734 \mathrm{~nm}$ after 15 min. The results were expressed as $\mathrm{IC}_{50}$ values. Ascorbic acid was used as the positive control.

\subsection{Determination of Total Phenolic, Flavonoid and Tannin Content}

The total phenolic content was evaluated using the Folin-Ciocalteu method [23]. In this method, the extract $(1 \mathrm{mg} / \mathrm{mL})$ was mixed with $1 \mathrm{~mL}$ Folin-Ciocalteu reagent and $46 \mathrm{~mL}$ distilled water. After $3 \mathrm{~min}, 3 \mathrm{~mL}$ of $2 \%$ sodium carbonate $\left(\mathrm{Na}_{2} \mathrm{CO}_{3}\right)$ solution was added. After keeping in the dark at room temperature for $2 \mathrm{~h}$, the absorbance of the samples was read at at $760 \mathrm{~nm}$. The results were determined as $\mathrm{mg}$ of Gallic acid equivalents (mg GAE/g extract).

The total flavonoid content of the extracts was analyzed according to Arvouet- Grand et al. [24]. In this method, $1 \mathrm{~mL}$ of $2 \% \mathrm{AlCl}_{3}$ was mixed with the same volume of extract solution ( $2 \mathrm{mg} / \mathrm{mL}$ ). After $10 \mathrm{~min}$ incubation at room temperature, the absorbance of the reaction mixtures were measured at $415 \mathrm{~nm}$. The flavonoid content was calculated from the quercetin standard curve (mg QEs/g extract). 
The tannin content was evaluated using the vanillin-HCL method of Broadhurst and Jones [25]. The test tubes were wrapped in aluminum foil. In these test tubes, the extract $(1 \mathrm{mg} / \mathrm{mL})$ was mixed with $3 \mathrm{~mL}$ vanillin reagent (4\% vanillin in methanol) and concentrated hydrochloric acid. Then the reaction mixture was left standing for $15 \mathrm{~min}$ at $20^{\circ} \mathrm{C}$. Absorbance of the solution was measured at $500 \mathrm{~nm}$. Tannin content was expressed as equivalents of catechin (mgCEs/g).

\subsection{Cytotoxic Activity}

The possible cytotoxic activity of different parts of $A$. acutifolius were evaluated using the Brine shrimp lethality bioassay [26]. The brine shrimps (Artemia salina) were hatched using A. salina eggs in a beaker, filled with air-bubbled sterile artificial seawater ( $3.8 \mathrm{~g}$ sea salt was dissolved in $100 \mathrm{ml}$ water) and left to incubate under artificial light for $24-48 \mathrm{~h}$ at $28^{\circ} \mathrm{C}$. In each experiment $0.5 \mathrm{~mL}$ of plant extract $(2 \mathrm{mg} / \mathrm{mL})$ was mixed with $4.5 \mathrm{~mL}$ of brine solution and the sample was tested at 1000,500,100,50 and 10ppm. Following incubation, active nauplii free from egg shells were collected and used for assay. Ten nauplii were drawn through a glass capillary and placed into test tubes containing different concentration of extracts and the control tubes. The extracts and controls tubes were maintained under artificial light for $24 \mathrm{~h}$ at $28{ }^{\circ} \mathrm{C}$. For each concentration of the extract and control, the number of dead shrimps were counted and recorded using an overhead projector. Larvae were considered dead if no movement of the appendage was observed within $10 \mathrm{sec}$. To determine the $\mathrm{LC}_{50}$ values, the data was analyzed using the EPA Probit Analysis Program (version 1.5) [27]. In the toxicity evaluation of plant extracts, $\mathrm{LC}_{50}$ values lower than $1000 \mu \mathrm{g} / \mathrm{mL}$ are considered to be bioactive [26]. The experiments were conducted in a set of three tubes per concentration and the controls.

\subsection{Statistical Analysis}

All analyses were performed in triplicate and the results presented as mean $\pm \mathrm{SE}$ (standard error). The results were analyzed using the MINITAB Statistical Package program. The variations between the different extracts were tested using Analyses of Variance (ANOVA) and a Tukey test was conducted to see how the groups differed from each other $(\mathrm{P}<0.05)$.

\section{RESULTS AND DISCUSSION}

\section{1. $\beta$-Carotene / Linoleic Acid and Phosphomolybdenum Antioxidant Activity}

In the present study, the potential of the plant to inhibit linoleic acid oxidation was evaluated using the $\beta$-Carotene/linoleic acid test system. The results showed that the ethanol extract of the fruit (AEF, 96.96 \pm 1.52 ) exhibited stronger antioxidant activity than the water extract of the fruit (AWF, 90.46 \pm 0.72 ), the water extract of the leaves (AWL, 88.86 \pm 0.80 ), the ethanol extract of the leaves (AEL, 82.41 \pm 0.25 ) and also standard antioxidant (BHT, $93.18 \pm 0.43$ ) (Figure 1). Antioxidants effectively inhibit linoleic acid oxidation and minimize oxidation of the lipid components in the cell membranes [28]. All of the extracts analyzed in this study exhibited strong antioxidant properties and they appeared to reduce the oxidation of linoleic acid, a key concern for the food industry.

The antioxidant capacity of the extracts evaluated using the phosphomolybdenum method, were in the range of $8.89-45.29 \mu \mathrm{g} / \mathrm{mg}$ (Table 1). The results revealed that ethanol extract of the leaves showed the highest and the water extract of the fruit showed the lowest antioxidant activity. Among the extracts of A. acutifolius analyzed in the present study, there were significant differences between the ethanol extract of the leaves and the water extract of the fruit $\left(\mathrm{F}_{3,20}=489.39 \mathrm{p}<0.001\right)$, but no differences were found between the antioxidant capacities of the water extract of the leaves and the ethanol extract of the fruit. The strong antioxidant capacity of the ethanol extract of the leaves of A. acutifolius may be attributed to the presence of phenolic content. 


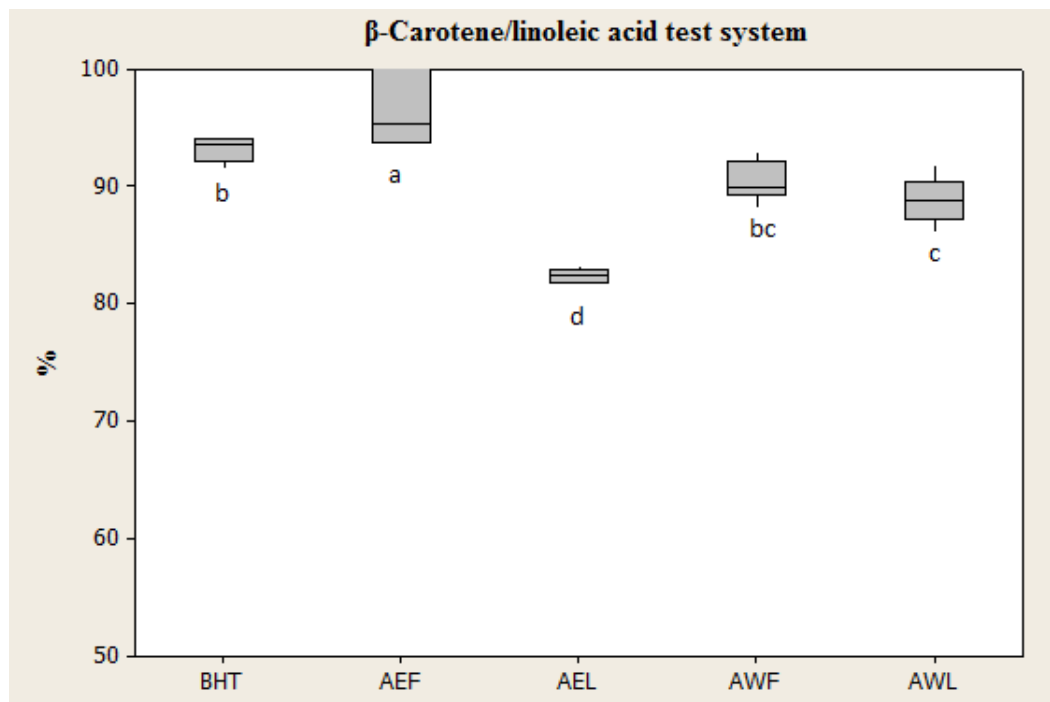

Figure 1. Antioxidant activity of A. acutifolius extracts

AEL: Ethanol extract of leaves of A. acutifolius; AEF: Ethanol extract of fruit of A. acutifolius; AWL: Water extract of leaves of A. acutifolius AWF: Water extract of fruit of A. acutifolius; BHT: Standard antioxidant; (different groups were shown with different letters on each boxplot)

Table 1. Antioxidant properties of A. acutifolius

\begin{tabular}{cccc}
\hline Sample & Phosphomolybdenum $(\mu \mathrm{g} / \mathrm{mg})$ & DPPH $\left(\mathrm{IC}_{50}\right)(\mathrm{mg} / \mathrm{mL})$ & ABTS $\left(\mathrm{IC}_{50}\right)(\mathrm{mg} / \mathrm{mL})$ \\
\hline AEL & $45.29 \pm 0.46^{\mathrm{a}}$ & $0.383 \pm 0^{\mathrm{d}}$ & $0.145 \pm 0.03^{\mathrm{cd}}$ \\
AEF & $16.61 \pm 0.13^{\mathrm{b}}$ & $3.990 \pm 0.17^{\mathrm{a}}$ & $1.815 \pm 0.02^{\mathrm{a}}$ \\
AWL & $19.13 \pm 1.12^{\mathrm{b}}$ & $0.799 \pm 0^{\mathrm{c}}$ & $0.214 \pm 0.04^{\mathrm{c}}$ \\
AWF & $8.89 \pm 0.76^{\mathrm{c}}$ & $2.967 \pm 0^{\mathrm{b}}$ & $0.838 \pm 0.01^{\mathrm{b}}$ \\
BHT & $\mathrm{nt}$ & $0.033 \pm 0^{\mathrm{e}}$ & $0.074 \pm 0^{\mathrm{d}}$ \\
\hline
\end{tabular}

AEL: Ethanol extract of leaves of A. acutifolius; AEF: Ethanol extract of fruits of A. acutifolius; AWL: Water extract of leaves of A. acutifolius AWF: Water extract of fruits of A. acutifolius; BHT: Standard antioxidant; nt: not tested

*Values are mean of three replicate determinations $(n=3) \pm$ standard error. Mean values followed by different superscripts in a column are significantly different $(\mathrm{p}<0.05)$.

\subsection{Radical scavenging activity (DPPH and ABTS)}

DPPH is a stable free radical and the lower the absorbance of the antioxidant and DPPH reaction mixture is, the higher the free radical scavenging activity of the antioxidant [29]. All extracts tested in the present study showed a radical scavenging capacity and among the extracts analyzed the ethanol extract of the leaves exhibited the highest radical-scavenging activity. All extracts were significantly different both from each other and the BHT IC $\mathrm{I}_{50}$ values $\left(\mathrm{F}_{4,25}=\right.$ $545.37 \mathrm{p}<0.001)$.

The ABTS scavenging capacity of the plant extracts was determined and the results are given in Table 1. The studied extracts showed scavenging activities in the range of 0.145-1.815 $\mathrm{mg} / \mathrm{mL}$. In addition, Zengin and Aktümsek [30] indicated that there was a correlation between the DPPH and ABTS methods. These results were in agreement with this study of Zengin and Aktümsek [30] and in the DPPH and ABTS assays, the ethanol extracts of the leaves showed the strongest radical scavenging activity. In addition, the ethanol extract of the leaves containing the highest amount of phenolic content. The phenolic content may be attributed to the DPPH and ABTS radical scavenging activity of the ethanol extract of the leaves. Our result confirmed the previous findings of Zengin and Aktümsek [30] and Uysal et al. [31]. 


\subsection{Total Phenolic, Flavonoid and Tannin Contents}

The total phenolic content in the ethanol and water extracts of the fruit and leaves from A. acutifolius ranged from 5.40 to $54.10 \mathrm{mgGAE} / \mathrm{g}$ (Table 2). As can be seen from Table 2, phenolic content was shown to be highest in the ethanol extract of the leaves, and to be lowest in the water extract of the fruit extract. The amount of phenolic content in the extracts varied according to the plant part and the solvent. These results were in accordance with the findings of Uysal et al. [31], these findings show that phenolic content may vary significantly between the different parts of the plants.

Table 2. Total flavonoid, phenolic and tannin content of A. acutifolius

\begin{tabular}{cccc}
\hline Sample & $\begin{array}{c}\text { Total phenolic content } \\
(\mathrm{mgGAEs} / \mathrm{g})\end{array}$ & $\begin{array}{c}\text { Total flavonoid content } \\
(\mathrm{mgQEs} / \mathrm{g})\end{array}$ & $\begin{array}{c}\text { Total tannin content } \\
(\mathrm{mgCEs} / \mathrm{g})\end{array}$ \\
\hline AEL & $54.10 \pm 0.67^{\mathrm{a}}$ & $92.70 \pm 0.21^{\mathrm{a}}$ & $37.72 \pm 0.51^{\mathrm{a}}$ \\
AEF & $5.68 \pm 1.25^{\mathrm{c}}$ & $13.05 \pm 0.37^{\mathrm{c}}$ & $25.97 \pm 0.17^{\mathrm{b}}$ \\
AWL & $24.92 \pm 1.58^{\mathrm{b}}$ & $21.87 \pm 0.12^{\mathrm{b}}$ & $25.97 \pm 0.36^{\mathrm{b}}$ \\
AWF & $5.40 \pm 0.62^{\mathrm{c}}$ & $11.07 \pm 0.05^{\mathrm{d}}$ & $24.47 \pm 0.17^{\mathrm{c}}$
\end{tabular}

AEL: Ethanol extract of leaves of A. acutifolius; AEF: Ethanol extract of fruit of A. acutifolius; AWL: Water extract of leaves of A. acutifolius AWF: Water extract of fruit of A. acutifolius

*Values are mean of three replicate determinations $(n=3) \pm$ standard error. Mean values followed by different superscripts in a column are significantly different $(\mathrm{p}<0.05)$.

The total flavonoid contents in the A. acutifolius extracts were determined using the spectrophotometric method with aluminum chloride and the results varied from 11.07 to 92.70 $\mathrm{mg}$ QEs/g extract (Table 2).

In the present study, tannin content was detected using the vanillin-HCL method and these results were evaluated as catechin equivalents. The total tannins content of the A. acutifolius extracts are presented in Table 2 and vary from 24.47 - $37.72 \mathrm{mgCE} / \mathrm{g}$. Phenolic compounds (such as phenolic acid, flavonoid and, tannin) are abundant in plants and have multiple biological effects including antioxidant activity. The determination of phenolic compounds in plants is very important in understanding their pharmacological properties and medicinal values. The results obtained in the present study showed that each extract of this plant had both a high phenolic content and a high antioxidant activity. This is an indication that the phenolic compounds present in the extracts are largely responsible for the antioxidant activity.

\subsection{Cytotoxic Activity}

The brine shrimp cytotoxic bioassay is considered to be useful tool for the preliminary assessment of general toxicity and for estimating the medium lethality concentration $\mathrm{LC}_{50}$. It has also been used for the detection of fungal toxins and pesticides [26, 32, 33] and universally as a test for detecting cytotoxic effects. Likewise, it is also frequently used in laboratories for the prescreening of plant extracts that have potential medicinal benefits, such as antimicrobial or antiparasitic [34-36]. In addition, the brine shrimp cytotoxic bioassay is highly sensitive to a variety of chemical substances [37] and only a small amount of sample is required [38].

The lethality of extracts are presented in Table 3 and show that the extracts possessed high cytotoxic activities against brine shrimp. The lethality of these extracts from A. acutifolius indicate the presence in this species of potent cytotoxic components, which require further investigation. The present study suggests the need for further investigations of this plant, in order to ascertain potential cytotoxic compounds. 
Table 3. Cytotoxic activity of A. acutifolius

\begin{tabular}{cc}
\hline Sample & $\begin{array}{c}\text { Cytotoxic activity }\left(\mathrm{LC}_{50}\right) \\
(\mu \mathrm{g} / \mathrm{mL})\end{array}$ \\
\hline AEL & 160.523 \\
AEF & 312.028 \\
AWL & 236.454 \\
AWF & 310.324
\end{tabular}

AEL: Ethanol extract of leaves of A. acutifolius; AEF: Ethanol extract of fruit of A. acutifolius; AWL: Water extract of leaves of A. acutifolius AWF: Water extract of fruit of A. acutifolius

\section{CONCLUSION}

The results revealed in the present study show that the ethanol and water extracts of the fruit and leaves of this plant have antioxidant properties. They also show that the plant possesses rich phenolic, flavonoid and tannin contents. Furthermore, all extracts show $\mathrm{LC}_{50}$ values of less than $1000 \mu \mathrm{g} / \mathrm{mL}$ and these results indicate that these parts of the plant possess strong cytotoxic activities. The present study suggests that this plant could be considered as a source of natural agents for the food industry and pharmacological applications. Further investigation is required to isolate and identify the antioxidant, and cytotoxic components found in this plant.

\section{Acknowledgements}

We thank all the lab members of the Secondary Metabolites Laboratory. We also state that there is no conflict of interest among the authors.

\section{Conflict of Interests}

Authors declare that there is no conflict of interests.

\section{ORCID}

\section{Arzu Kaska (iD https://orcid.org/0000-0002-0166-1818}

\section{REFERENCES}

[1]. Pandey, M., Abidi, A.B., Singh, S.\& Singh, R.P. (2006). Nutritional evaluation of leafy vegetable Paratha. Journal of Human Ecology, 19, 155.

[2]. Kindl, M., Blazekovic, B., Bucar, F. \& Vladimir-Knezevic, S. (2015). Antioxidant and anticholinesterase potential of Six Thymus Species. Evidence-Based Complementary and Alternative Medicine, 1-10. Doi: http://dx.doi.org/10.1155/2015/403950.

[3]. Bozzini, A. (1959). Revisione cito-sistematica del genere Asparagus L. I: Le specie di asparagus della flora italiana e chiave per la loro determinazione. Cariologia, 12, 199-264.

[4]. Fukushi, E., Onodera, S., Yamamori, A., Shiomi, N. \& Kawabata, J. (2000). NMR analysis of triand tetrasaccharides from asparagus. Magnetic Resonance in Chemistry, 38, 10051011.

[5]. Kim, B. Y., Cui, Z. G., Lee, S. R., Kim, S. J., Kang, H. K., Lee, Y. K. \& Park, D. B. (2009). Effects of Asparagus officinalis extracts on liver cell toxicity and ethanol metabolism. Journal of Food Science, 74, 204-208.

[6]. Makris, D. P. \&-Rossiter, J. T. (2001). Domestic processing of onion bulbs (Allium cepa) and asparagus spears (Asparagus officinalis): Effect of flavonol content and antioxidant status. Journal of Agricultural and Food Chemistry, 49, 3216-3222.

[7]. Sautour M., Miyamoto T. \& Dubois M.L. (2007). Steroidal saponins from Asparagus acutifolius. Phytochemistry, 68, 2554-2562.

[8]. Arcidiacono, S. \& Pavone, P. (1994). Erbe spontanee commestibili del territorio etneo. Bollettino Accademia Gioenia di Scienze Naturali, 27, 346-481. 
[9]. Venezia, A., Soressi, G.P., Falavigna, A. (1993). Aspetti relativi alla valorizzazione di specie di asparago spontanee in Italia. Agricoltura e Ricerca, 141, 41-48.

[10]. Di Maro, A., Pacifico, S., Fiorentino, A., Galasso, S., Gallicchio, M., Guida, V., Severino, V., Monaco, P. \& Parente, A. (2013). Raviscanina wild asparagus (Asparagus acutifolius L.): A nutritionally valuable crop with antioxidant and antiproliferative properties. Food Research International, 53(1), 180-188.

[11]. Martins, D., Barros, L., Carvalho, A.M., \& Ferreira, I.C.F.R. (2010). Nutritional and in vivo antioxidant properties of edible wild greens in Iberian Peninsula traditional diet. Food Chemistry, 125(2), 488-494.

[12]. Baytop T. (1999). Türkiye'de Bitkiler ile Tedavi. $2^{\text {nd }}$ ed., Nobel Kitabevleri, İstanbul, 184185.

[13]. Marc E.B., Nelly A., Annick D.D. \& Frederic D. (2008). Plants used as remedies antirheumatic and antineuralgic in the traditional medicine of Lebanon. Journal of Ethnopharmacology, 120, 315-334.

[14]. Fenga C., Costa C., Caruso E., Raffa L., Alibrando C., Gangemi S., Docea A.O. \& Tsatsakis A.M. (2016). Current evidence on the protective effect of dietary polyphenols on breast cancer., Farmacia, 64(1), 1-12.

[15]. Taskın, T. \& Bitis, L. (2016). In vitro antioxidant activity of eight wild edible plants in Bursa province of Turkey. Farmacia, 64(5),706-711.

[16]. Ferrara, L., Dosi, R., Di Maro, A., Guida, V., Cefarelli, G., Pacifico, S., Mastellone, C., Fiorentino, A., Rosati, A., \& Parente, A. (2011). Nutritional values, metabolic profile and radical scavenging capacities of wild asparagus (A. acutifolius L.). Journal of Food Composition and Analysis, 24, 326-333.

[17]. Kasture, S., Kasture, A., Ballero, M. \& Maxia, A. (2009). Antioxidant, anti-inflammatory, and adaptogenic activity of Asparagus acutifolius extract. Oriental Pharmacy and Experimental Medicine, 9(1), 83-89.

[18]. Palfi, M., Jurković, Z., Ćosić, J., Tomić-Obrdalj, H., Jurković, V., Knežević, N. \& Vrandečić, K. (2017). Total polyphenol content and antıoxıdant actıvity of wild and cultivated asparagus in croatia. Portal Znanstventh Casopisa Republike Hrvatske, 23(1), $56-62$.

[19]. Amin, I. \& Tan, SH. (2002). Antioxidant activity of selected commercial seaweeds. Malaysian Journal of Nutrition, 8(2), 167-177.

[20]. -Prieto, P., Pineda, M. \& Aguilar, M. (1999). Spectrophotometric quantitation of antioxidant capacity through the formation of a phosphomolybdenum complex: Specific application to the determination of vitamin E. Analytical Biochemistry, 269(2), 337-341.

[21]. Meriga, B., Mopuri, R., \& Krishna, T.M. (2012). Insecticidal antimicrobial and antioxidant activities of bulb extracts of Allium sativum. Asian Pacific Journal of Tropical Medicine, 5(5), 391-395

[22]. Shalaby, E.A., \& Shanab, S.M.M. (2013). Comparison of DPPH and ABTS assays for determining antioxidant potential of water and methanol extracts of Spirulina platensis. Indian Journal of Geo-Marine Sciences, 42(5), 556-564.

[23]. Slinkard, K. \& Singleton VL. (1977). Total phenol analyses: Automation and comparison with manual methods. American Journal of Enology and Viticulture, 28,49-55.

[24]. Arvouet-Grand, A., Vennat, B., Pourrat, A. \& Legret, P. (1994). Standardization of a propolis extract and identification of the main constituents. Journal de pharmacie de Belgique, 49(6), 462-468.

[25]. Broadhurst, R.B., \& Jones, W.T. (1978) Analysis of condensed tannins using acidified vanillin. Journal of the Science of Food and Agriculture, 29(9), 788-794. 
[26]. Meyer, B.N., Ferrigni, N.R., Putnam, J.E., Jacobsen, L.B., Nichols, D.E. \& McLaughlin, J.L. (1982). Brine Shrimp: A convenient general bioassay for active plant constituents. Planta Medica, 45(5), 31-34.

[27]. Finney DJ. (1971). Probit Analysis. 3rd ed. Cambridge University Press, Cambridge.

[28]. Tepe B., Daferera D., Tepe A.S., Polissiou M. \& Sokmen A. (2007). Antioxidant activity of the essential oil and various extracts of Nepeta flavida Hub.-Mor. from Turkey. Food Chemistry, 103,1358-1364.

[29]. Adıgüzel, A., Ozer, H., Sokmen, M., Gulluce, M., Sokmen, A., Kılıç, H., Sahin, F. \& Baris, O. (2009). Antimicrobial and antioxidant activity of the essential oil and methanol extract of Nepeta cataria. Polish Journal of Microbiology, 58(1), 69-76.

[30].Zengin, G. \& Aktumsek, A. (2014). Investigation of antioxidant potentials of solvent extracts from different anatomical parts of Asphodeline anatolica E. Tuzlaci an endemic plant to Turkey. African Journal of Traditional Complementary, and Alternative Medicines, 11(2), 481-488.

[31]. Uysal, S., Zengin, G., \& Aktümsek, A. (2016). Antioxidant properties and enzyme inhibitory effects of extracts from Mandragora autumnalis and its fatty acid composition. Marmara Pharmaceutical Journal, 20,144-151.

[32]. McLaughlin, J.L., Chang, C.J. \& Smith, D.L. (1991). Bench-top bioassays for the discovery of bioactive natural products: an update. In:Rhaman AU. (Ed). Studies in Natural Products Chemistry, Elsevier, 383-409.

[33]. Krishnaraju, A.V., Rao, T.V.N., Sundararaju, D., Vanisree, M., Tsay, H.S. \& Subbaraju, G.V. (2005). Assessment of bioactivity of Indian medicinal plants using Brine Shrimp (Artemia salina) lethality assay. International Journal of Applied Science and Engineering, 3(2), 125-134.

[34]. Adoum, O.A., Dabo, N.T. \& Fatobe, M.O. (1997). Bioactivities of some savanna plants in the brine shrimp lethality test and in vitro antimicrobial assay. International Journal of Pharmacognosy, 35(5), 334-337.

[35]. Mayorga, P., Perz, K.R., Cruz, S.M. \& Caceres, A. (2010). Comparison of bioassays using the anostracan crustaceans. Artemiz salina and Thamnocephalus platyurus for plant extract toxicity screening. Revista Brasileira de Farmacognosia, 20(6), 897-903.

[36]. Oliva, M. de las M., Gallucci, N., Zygadlo J.A. \& Demo, M.S. (2007). Cytotoxic activity of Argentinean essential oils on Artemia salina. Pharmaceutical Biology, 45(4), 259-262,

[37]. Svoboda, K.P. \& Hampson, J.B. (1999). Bioactivity of essential oils of selected temperate aromatic plants: antibacterial, antioxidant, anti-Inflammatory and other related pharmacological activities, Plant Biology Department, SAC Auchincruive, Ayr, Scotland, UK., KA6 5HW.

[38]. Hossain, A.M., Ferdous, T., Salehuddin, S.M. \& Das, A.K. (2009). In vitro cytotoxicity $\left(\mathrm{LC}_{50}\right)$ of extracts obtained from the seeds of Zea mays. Asian Journal of Food and AgroIndustry, 2(3), 336-34. 